\title{
Communicative approaches in computer-assisted language instruction (CALI)
}

\section{Jannie J. Botha}

This article maintains that software for computer-assisted language instruction is largely dominated by audio-lingual approaches, with their emphasis on drill-andpractice, structural drill and manipulation of discrete items. The writer pleads for a communicative approach in the design of software: present-day hardware is capable of handling such materials, which place the computer in the position of equal partner with the student in a simulated inter-communicative setting.

Hierdie artikel beweer dat programmatuur vir rekenaargesteunde taalonderrig grootliks oorheers word deur oudio-linguale benaderings, met die klem op driloefening, strukturele dril en die manipulering van afsonderlike items. Die skrywer bepleit 'n kommunikatiewe benadering tot die ontwerp van programmatuur, aangesien die apparatuur tans beskikbaar, geskik is vir die hantering van sulke materiaal, wat die rekenaar die student sy eweknieë maak in 'n gesimuleerde, inter-kommunikatiewe situasie.

We would be doing a great disservice to our discipline if we retreat and leave the translation of pedagogical principles to those primarily engaged in technological investigations. This in large measure explains the sorry state of computer software which continues to remain in an infantile stage, since a truly productive collaboration has not yet been arrived at between programmers and pedagogues. (Tuman 1985:2)

Computer-assisted language instruction has been in existence for a number of years. There is growing concern about the techniques used in courseware design, viz. language teaching techniques of the sixties combined with the technology of the 80 's.

This paper focuses on the need for a communicative approach in CALI (computer-assisted language instruction), and the way in which these needs can be satisfied. There seems to be no reason why communicative language teaching techniques can not be employed in CALI. Four major aspects will be discussed.

1 There is an increasing awareness of the need for communicative courseware to enhance classroom language teaching.

There is growing concern about the lack of communicative courseware for language teaching purposes (Sanders and Kenner 1983). If the current trend in the development of courseware continues, CALI could go the way of the language laboratory. It has also been documented in recent publications and reviews that (1) programming for language learning courseware has paid scant attention to the latest FL teaching methods; (2) there are few programs which employ branching 
techniques to accommodate students' learning; (3) commercial courseware for language learning has taken a step backwards in imitation of other non-language approaches. (Barrutia 1985:37).

Some years ago the language laboratory was introduced with great enthusiasm as a further enhancement of the audiolingual approach. It lent itself to the improvement of good language habits with the added advantage of individualization. A clear analysis of the reasons why the language laboratory did not live up to expectations shows that it was not technology per se which let it down, but rather the quality of the programs used and the lack of innovation in language teaching techniques which caused dissatisfaction with the language laboratory. Continual mechanical failures also discouraged teachers who used the laboratories.

Technology has now moved into the 80 's, and is fast approaching the 90's, but computer courseware for language teaching has remained in the 60's (Sanders and Kenner 1983). For a long time language teachers, who knew very little about computers, were so impressed with the form of the courseware that they paid little attention to the content. It still does not worry language teachers that the majority of language courses available for microcomputers still use the audiolingual approach. This lack of dissatisfaction may stem from two firmly established viewpoints among language teachers: (1) grammar has to be taught (cf. Elite Ohlstain: Grammar is alive and well and living in all language courses!) and a rigid, structural approach is an effective way of doing this. The computer lends itself well to this approach; (2) the audjolingual method with its drill-and-practice approach is still frequently used. Therefore teachers welcome courseware based on this approach.

Without going into too much detail about the nature of much of the courseware available, one can state that it tends to be in the structuralist tradition. It manipulates the basic grammar structures in a stimulus-response format. This type of courseware tends to be meaningless in the sense that it involves the manipulation of formal structures. According to Sanders and Kenner (1983) there are three reasons for the emphasis on this type of content: student demand, teachers' misunderstanding of the potential of the computer, and the belief that the computer as an interesting device will counteract boring drills.

There are three main uses of computers in language teaching: (Canale and Barker 1986):

- The computer as TUTOR. In theory this means the computer is used to teach the learner to play the role of master. It allows the learner to decide about the what, where and when of the learning activities. However, in practice the learner is rarely allowed such control when tutor software is designed or used.

- The computer as TOOL. When it is used in this way, it is not supposed to teach or drill, but merely to facilitate the learner's activities. But most software available for this purpose has not been designed for use as a tool. The result is that this mode of use does not produce significant results.

- The computer as TUTEE. If the computer is used in this way, the learner is supposed to teach the computer something (cf. the reasons for developing LOGO). In principle, the learner has control over the learning process. In practice, the learner can be so overwhelmed and confused that this use is also not realized.

The preceding comments about the use of computers in language teaching and the availability of appropriate courseware should leave no doubt that serious endeavours in the field of software development are needed to ensure a communicative approach in CALI.

\section{The principles of communicative language teaching should determine courseware development to ensure the availability of communicative courseware.}

There are certain principles (Johnson and Morrow 1981:60 ff.) which determine a communicative methodology, and which are also relevant to communicative approaches to CALI. A short discussion of these principles will provide the background to the viewpoint outlined in the statement above.

2.1 Know what you are doing: Every lesson should focus on performing an operation. For example, if a student has to learn to read technical material, he should be put in a situation where he can 
apply what he has learnt in the classroom. The same principle would apply to computer-base reading courses. A student who has a specific goal in mind will not be satisfied when he has t look at a dragon gulping up words he could not identify in a technical text. Well-defined goa for a language learner are often lacking in courseware. If a data base is included in a program $\mathrm{s}$ that a student has an easily accessible dictionary facility for explanations of difficult words, will give him the feeling that he is making progress in a goal-oriented way.

2.2 The whole is more than the sum of the parts: A significant feature of communication is that it is dynamic, improvising process. A communicative methodology should therefore operate wit large stretches of language above the sentence level, and it should operate with real language Even if a student knows all the grammar of the language he is learning, it does not guarante that he will be able to use the language.

Existing approaches to courseware design are the antithesis of this principle. By concentratin exclusively on grammatical competence (in software) students may get the wrong impression abol communicative performance. If language is chopped into small, discrete items (for easy progran ming) it defeats the purpose of learning real discourse, as well as the potential of the computer $t$ handle it. The computer (from a hardware viewpoint) can handle larger stretches of language, an should be put to work to do this. By incorporating peripherals such as video, tapes and cassett recorders, courseware can come much closer to real-life situations.

2.3 The processes are as important as the forms: The process of real communication should $b$ duplicated as far as possible. This means that practising the form of the communication act $i$ the target language should also take place in a communicative framework. In this regard ther should be provision for three different, but closely linked, processes in the communicatio situation: (a) an information gap - one student has information which the other one does nc have and which they want to share; (b) a choice - in a communication situation a participar should be able to choose what he wants to say and how he wants to say it. Of course, the sam principle would apply to the person who has to respond; (c) feedback - this process is implicit i the two processes already mentioned.

Taken together, the three processes outlined above seem to be important in the development communicative courseware. There is little purpose in teaching students everything about th structure of language, but very little or nothing about the processes involved in communication. A three processes referred to above can be incorporated into courseware. Simulation activities, $\mathrm{fc}$ example, allow for the inclusion of an information gap process - not to be confused with gap-fillir exercises. By allowing the computer to share information with the student, and one student wif another in small group work, students can discover the value of this process.

The second process, viz. choice, is far more problematic in courseware. This process calls for an ope endedness which is usually not associated with computers - the latter tend to be linked with accural number, or discrete item crunching. On the other hand, choice calls for language processing whic approaches Artificial Intelligence, and natural language processing.

Feedback (the third process mentioned) should be explicit in courseware. It seems to call for mo effective responses than "Very good", "Excellent work", and "You're a genius!" It should resemb real-life language responses. This requirement illustrates the need for a more innovative approach courseware design than is found at present.

2.4 To learn it, do it: It is widely accepted that language teaching should also be concerned wi language learning. What happens in the classroom or at the computer should actively invol the learner and must be judged in terms of the effects on him. Learning a language shou become the responsibility of the learner as well.

This principle has serious implications for a communicative approach in CALI. As long as coursewa requires a student to remain a presser of keys, inactive, instead of becoming actively involved in t] learning process, CALI is on dangerous ground, damaging its own image. Communicati 
courseware should involve the student to such an extent that he learns language, and is motivated to apply his knowledge at every opportunity.

2.5 Mistakes are not always mistakes: Communicative language teaching was often criticized for allowing students to make mistakes, particularly grammatical ones. One must remember that even native speakers of a language tend to make mistakes (Sobahle 1986). It is therefore unfair to expect second or foreign language students not to make mistakes when using the target language.

One has to distinguish here between so-called trivial mistakes of grammar and pronunciation which do not seriously hamper the conveying of a message, and serious mistakes which do lead to a breakdown in the communication process.

This principle may be the most difficult for courseware designers to accept. The computer is known for its ruthlessness in pointing out mistakes to learners. Many techniques have been employed in courseware to soften the rather harsh judgement of computers but the fact remains that most programs will hardly tolerate a missing / $/$ for the third person singular. It does not really soften the blow for a learner to be told: "I think one should always remember that something must be added to a present tense verb when its subject is he/she/it".

It should not be inferred from what has been said so far that the structure of language (grammar) is unimportant in computer courseware. However, there is more to learning a language on the computer than merely doing drill-and-practice exercises and never reaching a stage where communication can begin to take place.

\section{The communicative teaching of different language skills on the computer is possible from a hardware point of view.}

When communicative CALI is approached from the principles outlined above, it calls for a fresh look at the state of the hardware as well as the type of programs used. Some approaches underlying communicative language teaching lend themselves to the use of the computer (Mydlarski 1985).

Students who are already computer literate are more relaxed at a computer than in a classroom situation. This is due to the privacy offered by the computer and also by the impersonal feedback provided by computers. According to Mydlarski the user exercises control over the program in varying degrees and this enhances the student's self-image.

Communicative approaches usually rely heavily on problem-solving activities. The computer is renowned for this type of activity. Problem-solving is also an integral part of daily language use. It is therefore important that learners are exposed to this type of activity in the learning situation. It should be pointed out that problem-solving in this sense need not always concentrate on languagerelated activities per se. If non-language problem-solving programs are employed in a small group situation, this could be advantageous to language learners. (Cf. The Factory and The Pond-Sunburst Communications).

The processing speed of computers makes problem-solving an ideal activity for communicative CALI. If problem-solving is applied in a small group situation it could help students to practise their speaking abilities. One should, however, be carefully optimistic about the conversational spin-off from this type of activity. In an experiment at Ealing College, London (Piper 1986), it became clear that the conversation among participants did not yield the expected results. Only after some other preparations had been incorporated into the program, e.g. student preparation, did the conversational spin-off become worthwhile.

As far as listening comprehension is concerned, interesting new possibilities are now becoming a reality. The decrease in the price of hard disks makes it possible to store real (language) sound on such a disk and use it interactively for listening comprehension exercises, and the interactive teaching 
of vocabulary in foreign languages or for special purposes. If this activity is linked with interactiv video, it opens many new and exciting possibilities for listening comprehension. At the University o Stellenbosch such an experiment has now been running for six months. The first material (in Xhosa an African language) is at present being prepared for student use. No statistical evidence is availabl at the time of writing but the experiment promises to be an improvement over the languag laboratory. The fact that a student has random access to any part of the sound on the hard disk, fo example, is in itself an improvement over the linear availability of sound on a cassette player in language laboratory.

This facility also opens interesting ways of teaching students more advanced listening skills such a note-taking. The latter is usually a problem for students. It is even more so for students in journalism

\section{New developments in artificial intelligence promise improvements in communicative CALI}

Early developments in CALI concentrated on using the computer in asking questions while th learner's task was to respond. but this approach should be regarded as a very limited way of usin computer technology (Mydlarski 1985:79). Higgins (1983:4) sees different roles for the computer, viz a task-setter, an opponent in games, an environment, a conversational partner, a stooge or a tool. Fo an explanation of these roles the reader is to referred to Higgins and Johns (1984).

With regard to the environment, learners are now able to control their learning style. The emergenc of so-called "expert systems" with their roots in Artificial Intelligence promises to revolutionize th field. Although the term communication usually refers to a process where two or more persons ar involved, there is much to be said for a computer program which takes individual learning styles int account - communication is to a large extent also linked to an individual style.

With regard to the different learning styles referred to above, we should look for programs whicl provide different routes for different students. It is in this sense that Barrutia (1985:37) maintains tha expert systems could provide answers to the present unacceptable state of courseware. An exper system can help a student in the following ways: it can (a) solve problems, (b) make predictions, (c suggest positive treatment, and (d) offer advice with a degree of accuracy resembling its huma counterpart.

Expert systems can keep a record of a student's right and wrong answers, record what style made th best answers possible, and then indicate the best kind of display for a specific student. Th characteristic of expert systems holds much promise for communicative computer-assisted languag instruction. When two students (each with his/her own learning style) work on a simulation, th programs developed under an expert system should be able to accommodate each student's learnin style. At present, even the best designed simulation will have difficulty in doing this. It therefor means that at least one student has to adapt his learning style for the duration of the simulation. I real terms it means that both students must adapt their learning styles because no specific style w: catered for in the courseware design. (See Barrutia 1985:38 for an exposition with regard 1 courseware in which an expert system is employed.)

Every language teacher knows that natural language is a very complex phenomenon. Syntact complexity is a problem in itself, but meaning is even more complex. With reference to the processir of meaning, natural language processing is still very primitive. Linguists have been working for sorr time on language understanding programs that will allow computer users to communicate with th computer in normal English sentences rather than in computer jargon.

One of the best-known conversational programs, ELIZA, dates back to 1966 (created by Joser Weizenbaum). What actually happened in this program was not really "understanding" but simp the appearance of understanding. The program was built around the principle of key word matching

Very often conversation with a computer turned out to be the typing in of verb forms (Underwor 
1984:71). He mentions some programs which have been making use of real language input, e.g. $S P I O N$ in German. This program understands student input and can also recognize certain kinds of mistakes in grammatical structure.

Some very complicated systems have been developed which eventually were used only for more sophisticated error judging (cf. DART, as described by Cerri and Breuker in Underwood 1984:72).

When looking at communicative approaches in CALI, we should remember that the contextualization of language is in itself not communication. This statement should make it clear that there is no easy way out of the dilemma of inadequate courseware. Meaningful drills do not and never will constitute communicative language learning. Communicative drills, on the other hand, require students to add new information about the real world even though the language structures may be controlled. If language teaching programs were to move closer to real communication (for example by using expert systems) they should allow students to start asking the questions. In other words, they would open the way to real two-way communication and thereby abandon computer monologues.

At present, existing courseware bears evidence of limited thinking, efforts, and imagination (Barrutia 1985:40), and this has only aggravated the problem. The microprocessor should be given a chance to show what it can really do with branching.

We cannot blame the lack of communicative courseware on the hardware. High quality visuals and sound are already available at reasonable prices. By using interactive videodisc and real sound from a hard disk, many new approaches in listening comprehension are possible. Foreign language films and video tapes are creating brand new opportunities for communicative approaches in computer-based listening comprehension. This is but one example to show that hardware is not deterring courseware designers from adopting a communicative approach for their courses. As Barrutia (1985:42) aptly puts it: "We need to think not in terms of grander hardware, but rather in terms of making the hardware conform to grander and more humanistic programs."

One can therefore agree with Underwood that language teachers should use computers in a way which goes beyond the trivial manipulation of discrete grammar points and isolated vocabulary items. By looking at CALI courseware from a communicative viewpoint, we realize that we are only now starting to scratch the surface. It will be much harder to create communicative courseware but it also presents a challenge to motivated language teachers. If we don't do this, we may find ourselves in the same position as those who regarded the language laboratory as the most exciting tool available for language teaching, only to become bitterly disappointed with the results.

As early as 1968 Richard Bolt stated that computer-assisted instruction should rather be labelled "teacher-assisted instruction," for there "can be no better 'communicative' learning environment than the warm and responsive presence of other human beings." (Bolt 1968:90). The question therefore remains: how close can CALI come to creating such a communicative environment?

\section{Bibliography}

BARRUTIA, RICHARD. 1985. Communicative CALL with artificial intelligence: some desiderata. CALICO Journal 3(1): 37-42.

BOLT, RICHARD H. 1968. Computer-assisted Socratic instruction in Orr, William D. (Ed.). Conversational computers. New York: John Wiley.

CANALE, MICHAEL \& Graham Barker. 1986. How creative language teachers are using microcomputers. TESOL Newsletter 20(1) Supplement 3: 1-3.

HIGGINS, JOHN. 1983. Computer-assisted language learning. Language Teaching. Vol 16 No 2 pp 102-114.

Higgins, JOHN \& Tim Johns. 1984. Computers in language learning. London: Collins Educational Publishers. 
JONES, GLYN. 1986. Computer-simulations in language teaching - the Kingdom experiment System 14(2): 179-186.

JOHNSON, KEITH \& Keith Morrow. 1981. (Eds.) Communication in the classroom. London Longman.

MYDLARSKI, DONNA. 1985. How communicative can a computer be? The Canadian Modern Language Review 42(1): 75-82.

PARAMSKAS, D.M. 1986. Artificial Intelligence in computer-assisted language instruction. Th Canadian Modern Language Review 42(3): 619-628.

PIPER, ALISON. 1986. Conversation and the computer: a study of the conversational spin-of generated among learners of English as a foreign language working in groups. System 14(2) 187-198.

SANDERS, DAVID \& Roger Kenner. 1983. Whither CAI? The need for communicativ courseware. System 11(1): 33-39.

SOBAHLE, P. 1986. Error analysis and its significance for second language teaching and learning Per Linguam Vol 2 No. 2.

TUMAN, W.V. 1985. Technology and its implications for language teaching. Paper presented at the joint meeting of AATF/AATG/AATI/AATSP/ACTFL, New York.

UNDERWOOD, JOHN H. 1984. Linguistics, computers and the language teacher - a communicativ approach. Rowley: Newbury House Publishers. 